\title{
Diagnostic accuracy and cytomorphology analysis of fine-needle aspiration of salivary glands
}

\author{
Lisnawati, Marini Stephanie, Chairil Hamdani \\ Department of Anatomical Pathology, Faculty of Medicine, Universitas Indonesia / Dr. Cipto Mangunkusumo Hospital, Jakarta, Indonesia
}

\begin{abstract}
Abstrak
Latar belakang: Sitologi aspirasi jarum halus merupakan metode yang efektif dan aman dalam menilai lesi kelenjar liur. Gambaran morfologi yang bervariasi serta sitomorfologik yang saling tumpang tindih, mengakibatkan sulitnya dalam mendiagnosis lesi kelenjar liur. Penelitian ini bertujuan untuk mengetahui akurasi diagnostik dan menganalisa gambaran sitomorfologik aspirasi lesi kelenjar liur.
\end{abstract}

Metode: Dilakukan penelusuran sediaan sitologik lesi kelenjar liur tahun 2005-2009 pada arsip Departemen Patologi Anatomik FKUI/RSCM. Didapatkan 107 kasus sitologi lesi kelenjar liur, dan dilakukan pemeriksaan ulang. Terdapat 7 kasus dieksklusi karena sediaan tidak layak baca. Dilakukan pula penelusuran sediaan histopatologiknya dan dikorelasikan dengan sediaan sitologik. Uji diagnostik diaplikasikan pada 39 kasus berpasangan sitologi-histopatologik.

Hasil: Kasus lesi kelenjar liur dari tahun 2005-2009 berjumlah 100 kasus, diantaranya 27 kasus negatif, delapan kasus inkonklusif dan 65 kasus lesi neoplastik. Pada 39 kasus berpasangan, empat belas kasus diantaranya memiliki diagnosis berbeda, dengan 3 kasus negatif palsu, satu kasus positif palsu. Secara keseluruhan dalam membedakan lesi malignant atau non-malignant didapatkan sensitivitas 82,35\%, spesifisitas 95,45\%, NPV 87,5\% dan PPV 93,34\%.

Kesimpulan: Penelitian ini menunjukkan bahwa akurasi diagnostik sitologi lesi kelenjar liur sangat bervariasi, dengan sensitivitas $82,35 \%$ dan spesifisitas 95,45\% dalam membedakan lesi malignant atau non-malignant; sekalipun tidak dapat menegakkan diagnosis definitif, namun tetap dapat membantu klinisi dalam tata laksana kasus. (Med J Indones. 2012;21:92-6)

\begin{abstract}
Background: Fine-needle aspiration (FNA) is an effective and safe procedure for analyzing salivary gland lesions. Various morphological and overlapping cytomorphology features can bring difficulty in diagnosis of the salivary gland lesions. This study aimed to evaluate the diagnostic accuracy of fine needle aspiration cytology of salivary glands lesions.

Methods: There were 107 cases of cytology and 39 cases of histopathology of salivary gland lesions collected and reviewed from the archives of Anatomical Pathology Department, Faculty of Medicine, Universitas Indonesia / Cipto Mangunkusumo Hospital from 2005-2009. Seven cases of cytology were excluded, due to unsatisfactory specimens. Diagnostic test was applied to analyze the 39 pairs of cytology-histopathology cases.

Results: There were 100 cases of salivary gland lesions cytology obtained, consisted of 27 negatives, eight cases inconclusive and 65 cases of neoplastic lesions. Of the 39 pair cases, fourteen cases showed result discrepancies between cytology and histopathology, with 3 false-negative cases and 1 false-positive case. The sensitivity and specificity of cytology analysis in differentiating malignant from non-malignant lesions were $82.35 \%$, and $95.45 \%$ respectively, NPV $87.5 \%$ and PPV 93.34\%.

Conclusion: This study showed diagnostic accuracy of FNA cytology salivary gland lesions was varied, with $82.35 \%$ sensitivity and $95.45 \%$ specificity in differentiating malignant from non-malignant hence this information can still be used for case management. (Med J Indones. 2012;21:92-6)
\end{abstract}

Keywords: FNA cytology, salivary gland lesions

Salivary gland neoplasms represent approximately $6 \%$ of all head and neck tumors. The global annual incidence of salivary gland tumors varied from $0.4-$ 13.5 cases per 100000 populations. Cancer registry of Indonesian Association of Anatomical Pathology in 2005 reported 120 cases $(0.90 \%)$ of salivary gland neoplasm in pathology-based report from 13 centers in Sumatera, Java, Bali, and Kalimantan. ${ }^{1,2}$

Fine needle aspiration biopsy (FNA) is still regarded an effective and safe procedure for salivary gland lesions, due to the superficial location for FNA procedure and its usefulness for analyzing salivary gland lesions where the clinical and radiological data per se are not sufficient for diagnosis. Although FNA is less accurate in diagnostic, it causes less morbidity than the biopsy which quite often cause tumor contamination. Furthermore, for lesions around the neck and jaw area, FNA can help to determine the origin of the lesions whether it comes from salivary gland, non-neoplastic or neoplastic, benign or malignant, primary or metastatic.,

Salivary gland neoplasms possess various morphological features and their cytomorphology can be similar among them; when this is followed by inadequate sampling and misinterpretation, it will result as false positive or false 
negative. A number of studies have shown the diagnostic accuracy of salivary FNA was $81-98 \%$ sensitivity and $1-14 \%$ false positive. ${ }^{1}$ The aim of this study was to evaluate the diagnostic accuracy of fine needle aspiration cytology of the salivary gland lesions.

\section{METHODS}

One hundred and seven cases of cytology salivary gland lesions were collected and reviewed from the archives of Anatomical Pathology Department, Faculty of Medicine, Universitas Indonesia / Cipto Mangunkusumo Hospital from 2005-2009; seven cases were excluded due to unsatisfactory specimens. The follow-up histopathologic diagnosis from the same patient were also collected. The cytology slides were stained with Papanicolaou and Giemsa, while the histopathology slides with Hematoxylin and eosin (HE). The clinical information such as gender, age, and location of lesions were recorded.

The cytomorphological results were classified into four groups as negative, inconclusive, benign and malignant. The result was regarded negative if no malignant cell was found or it was non neoplastic such as inflammation eg. chronic sialadenitis, sialadenosis. Inconclusive cases were assigned when atypical cells were found and suspicion for malignancy. Benign was assigned following World Health Organization (WHO) classification; such as pleomorphic adenoma, warthin's tumor, etc. Malignancy was assigned if malignant cells were found; this was later described according to WHO classification criteria. Carcinoma NOS (not otherwise specified), was assigned if it was difficult to decide the histopathologic type.

The histopathology results were classified into three groups as non neoplastic, benign and malignant neoplasms. The results were assigned similar to the cytology results. False negative refers to incorrect result where malignant lesions were diagnosed as negative or benign lesions. False positive refers to incorrect results where benign or negative lesion was diagnosed as malignant lesions. Diagnostic test was applied to analyze the data from the 39 pairs of cytology-histopathology cases to determine the sensitivity and specificity.

\section{RESULTS}

One-hundred cases of cytology salivary gland lesions were obtained from the archives Anatomical Pathology Department between 2005-2009. Twentyseven cases were negative, eight cases were inconclusive and 65 cases were neoplastic lesions which consisted of 37 cases of benign lesion and 28 cases of malignant lesion (Table 1). The benign lesions were histopathologically confirmed as pleomorphic adenoma, canalicular adenoma, warthin's tumor and benign mesenchymal lesions which was hemangioma. Malignant lesions were histopathologically confirmed as mucoepidermoid carcinoma, adenoid cystic carcinoma, acinic cell carcinoma, squamous cell carcinoma, poorly differentiated carcinoma, nonHodgkin lymphoma, malignant mesenchymal lesions which was rhabdomyosarcoma and carcinoma NOS.

Both benign and malignant lesions were mostly located in the parotid gland with 28 cases (42\%) and 23 cases (35\%) respectively, followed by submandibular gland with 9 cases (14\%) for benign group and 5 cases $(8 \%)$ for malignant group. Range of patients' age for the benign lesions was 3 months to 82 years old, with median 40 years old; whereas the malignant lesions were from 8 78 years old, with the median 49 years old. The youngest subject in the benign group lesions had hemangioma, in the malignant group was with rhabdomyosarcoma. Females were more frequently affected than the male in both benign and malignant groups with 23 cases (36\%) and 17 cases $(26 \%)$ respectively. The frequency of malignant tumor showed tendency to increase by age (Table 2 ).

There were 39 cases with paired cytology and histopathology diagnosis. Pleomorphic adenoma was the most common lesion, followed by mucoepidermoid carcinoma and warthin's tumor. The correlation between diagnoses based on FNA cytology and histopathology was shown in table 3 . There were 14 cases showing result discrepancy, consisted of 3 cases of false negatives, one case of false positive, four cases of misdiagnosis benign lesions as negatives and 6 cases with discrepant type of malignancy.

The 3 false negative cases consisted of 2 cases of mucoepidermoid carcinoma was assigned negative by cytology and 1 case of adenoid cystic carcinoma was diagnosed as pleomorphic adenoma by cytology. The false positive case was sialadenosis on histopathology examination but was diagnosed as acinic cell carcinoma by cytology. Three cases of warthin's tumor and one canalicular adenoma case were interpreted cytologically as negative with normal portion. There were 6 cases with discrepant type of malignancy consisted of two mucoepidermoid carcinoma, one acinic cell carcinoma and one rhabdomyosarcoma were diagnosed cytologically as carcinoma NOS; the last two cases were carcinoma NOS and high grade mucoepidermoid carcinoma were diagnosed cytologically as poorly differentiated carcinoma NOS. The accuracy of FNA in differentiating malignant from non-malignant lesions revealed sensitivity, specificity, NPV (negative predictive value) and PPV (positive predictive value) of $82.35 \%, 95.45 \%, 87.5 \%$ and $93.34 \%$ respectively. 
Table 1. Distribution of salivary gland lesions based on cytology results at Anatomical Pathology Department, FMUI/CMH 2005-2009

\begin{tabular}{lcccccc}
\hline \multicolumn{1}{c}{ Cytology } & 2005 & 2006 & 2007 & 2008 & 2009 & Total \\
\hline Negative & 9 & 6 & 3 & 1 & 8 & 27 \\
inconclusive & 3 & 1 & 2 & 2 & 0 & 8 \\
Neoplastic lesions & 27 & 8 & 13 & 6 & 11 & 65 \\
Total & 39 & 15 & 18 & 9 & 19 & 100 \\
\hline *FMUI/CHM= Faculty of Medicine Universitas In
\end{tabular}

*FMUI/CHM= Faculty of Medicine, Universitas Indonesia / Cipto Mangunkusumo Hospital

Table 2. Clinical characteristic of salivary gland neoplasms at Anatomical Pathology Department, FMUI/CMH 2005-2009

\begin{tabular}{lccc}
\hline \multicolumn{1}{c}{ Characteristics } & Benign (\%) & Malignant (\%) & Total (\%) \\
\hline Site & & & \\
Parotid gland & $28(43)$ & $23(35)$ & $51(78)$ \\
Submandibular glands & $9(14)$ & $5(8)$ & $14(22)$ \\
Sex & & & \\
Female & $23(36)$ & $17(26)$ & $40(62)$ \\
Male & $14(21)$ & $11(17)$ & $25(38)$ \\
Age & & & $8(12)$ \\
$0-20$ & $6(9)$ & $2(3)$ & $9(14)$ \\
$21-30$ & $6(9)$ & $3(5)$ & $10(15)$ \\
$31-40$ & $7(11)$ & $3(5)$ & $12(19)$ \\
$41-50$ & $6(9)$ & $6(9)$ & $16(25)$ \\
$51-60$ & $6(9)$ & $10(15)$ & $10(15)$ \\
$>61$ & $6(9)$ & $4(6)$ & \\
\hline
\end{tabular}

*FMUI/CHM= Faculty of Medicine, Universitas Indonesia / Cipto Mangunkusumo Hospital

Table 3. Correlation of FNA cytologic and histopathologic diagnosis in 39 cases of salivary gland lesions

\begin{tabular}{lcccc}
\hline \multirow{2}{*}{ Cytology } & \multicolumn{3}{c}{ Histopathology } & Total \\
\cline { 2 - 4 } & $\begin{array}{c}\text { Malignant } \\
\text { lesions }\end{array}$ & $\begin{array}{c}\text { Benign } \\
\text { lesions }\end{array}$ & Nonneoplastic & \\
\hline Malignant lesions & 14 & 0 & 1 & 15 \\
Benign lesions & 1 & 12 & 0 & 13 \\
Negative & 2 & 4 & 5 & 11 \\
Total & 17 & 16 & 6 & 39 \\
\hline
\end{tabular}

\section{DISCUSSION}

Parotid gland was the most common site for neoplastic lesions with approximately $80 \%$ of all salivary gland neoplasms and pleomorphic adenoma was the most common neoplasms type, it accounts for about $60 \%$ of all salivary gland neoplasms; similar to our finding in this study. ${ }^{1,5,6}$

We found 14 cases with discrepancies between cytologic and histopathologic diagnoses. The two false negative cases of mucoepidermoid carcinoma occurred because only the inflammatory area was taken by FNA. The histopathologic sections showed neoplastic component consist of epidermoid and mucus cells with inflammatory reaction, and area of severe inflammation without neoplastic component. Lurie et $\mathrm{al}^{7}$ also reported a significant number of falsenegative cases by cytology was due to inadequate specimens and obtained only the peripheral part of carcinoma which was normal area with inflammatory 
reaction. ${ }^{7}$ Differentiating pleomorphic adenoma from adenoid cystic carcinoma in cytological procedure could be difficult if the samples were inadequate with less extracellular matrix. There was overlapping matrix features in both lesions. Matrix in adenoid cystic carcinoma can focally look fibrillary, similar to pleomorphic adenoma. In this condition the shape of matrix was important to differentiate both lesions. ${ }^{6}$ As well as the characteristic of cells and nuclear atypia should be carefully evaluated. Several studies reported that cytologic diagnosis of pleomorphic adenoma was the most frequently misdiagnosed. Zhang et $\mathrm{al}^{3}$ and Jan et $\mathrm{al}^{8}$ reported false negative interpretation of adenoid cystic carcinoma as pleomorphic adenoma due to scanty hyaline spherical globules and the prominent myxoid or fibrillary chondromyxoid substances, where in our case due to the difficulty of finding the hyaline globul and abundant of tumor cells embedded among matrix with indistinct edge (Figure 1).
The only one false positive interpretation was sialadenosis with strong inflammatory reaction which had atypical cells and misinterpreted as acinic cell carcinoma (Figure 2). Sialadenosis in FNA cytology is commonly cellular and consists of normal salivary gland portion with hypertrophic acini cells. ${ }^{6}$

Well-differentiated acinic cell carcinoma was difficult to differentiate with normal acinar cell, but usually normal acinar cell form cohesive monolayer cells, meanwhile the tumor cells formed larger and irregular cluster or composed as single cell. In the case of acinic cell carcinoma, normal part such as adipose tissue and ductal cells usually do not exist. ${ }^{9}$

Three warthin's tumor cases and 1 canalicular adenoma case were interpreted cytologically as negative with only normal portion. These differences had no clinical impact because both diagnosis meaning no malignant cell.
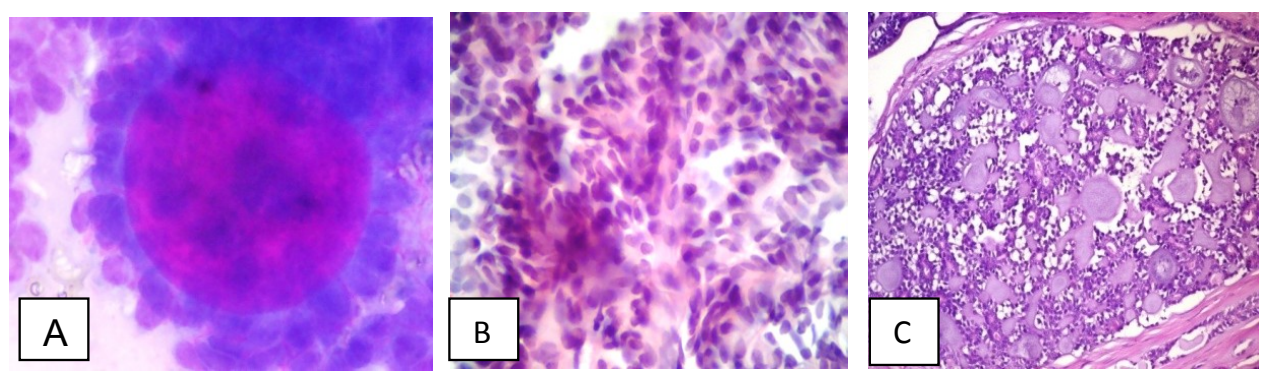

Figure 1. Adenoid cystic carcinoma. A. Cytologic smear showing hyaline spherical globule surrounded by basaloid cells, giemsa, 1000x; B. Cytologic smear showing cells that embedded among matrix with indistinct edges. Papanicolaou, 400x; C. Neoplastic component consist of tumor cell with cribriform architecture, composed by basaloid and myoepithelial cells, HE, $100 X$


Figure 2. Sialadenosis. A. Cytologic smear showed atypical cells, Papanicolaou, 1000X; B. Hypertrophic acini cells with severe inflammatory reaction, $\mathrm{HE}, 100 \mathrm{X}$
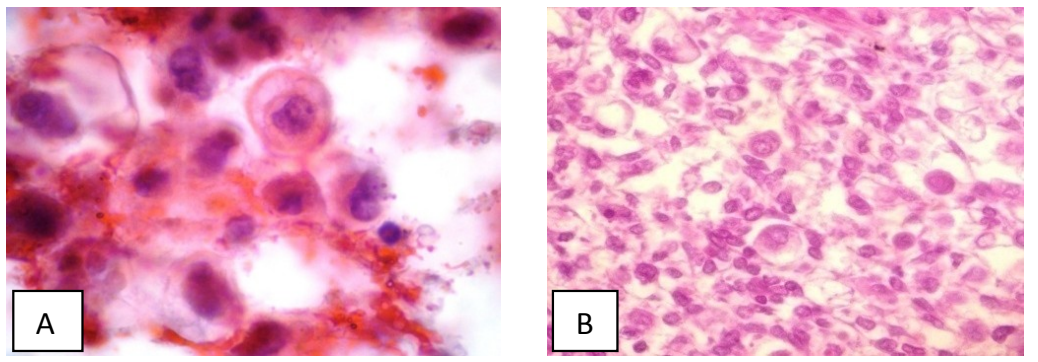

Figure 3. Rhabdomyosarcoma. A. Cytologic smear showed tumor cell with round nuclei and clear cytoplasm, Papanicolaou, 1000x; B. Round/spindle cells with eosinophilic/clear cytoplasm, HE, 400x 
There were 6 malignancy cases which showed discrepancies in the histopathologic types interpretation/ diagnosis. In the rhabdomyosarcoma case, the histopathology section showed a lot of tumor cells with round nuclei and clear cytoplasm and sparse spindle cells that were also found in the cytologic smear and misinterpreted as carcinoma in FNA cytology (Figure $3)$. Rhabdomyosarcoma is a rare malignant tumors of striated muscle in salivary glands. Literatures had reported cases of rhabdomyosarcoma of salivary gland found in children. They reported the presence of difference populations of malignant cells ranging from small, round cell tumor to spindly tumor cells. ${ }^{10}$ The last 5 cases were misinterpreted due to lack of the exceptional characteristic that define the type of malignancy, such as the two mucoepidermoid cases diagnosed as carcinoma NOS in FNA cytology, because the difficulty to find mucus cells and epidermoid cells.

A number of literatures have examined the diagnostic accuracy of FNA cytology of salivary gland lesions. Lurie et $\mathrm{al}^{7}$ reported 52 FNA cytology samples of salivary gland lesions with 16 false negative cases, sensitivity $66 \%$ and specificity $100 \%$. Zhang et $\mathrm{al}^{3}$ reported 86 FNA cytology samples with sensitivity $89.4 \%$ and specificity $79.1 \%$ with 10 false negative cases, and 5 false positive cases. Lukas et $\mathrm{al}^{11}$ reported 121 samples of salivary gland lesions with 12 false negative cases, 1 false positive case, sensitivity $85 \%$ and specificity $97.5 \%$. Colella et $\mathrm{al}^{12}$ conducted systematic reviewed in 16 literatures of FNA cytology salivary gland lesions and reported $16.14 \%$ cases with discordant of histopathologic type of malignancy and concordance of $79.95 \%$ and discordant in $20.04 \%$ in detecting malignant neoplasms.

Our study showed FNA had high sensitivity and specificity in differentiating malignant from non-malignant lesions eventhough there were 4 misdiagnosed cases of benign neoplasm reported as negatives and 6 discrepant type of maligancy. It is suggested to report it as open diagnosis which allows other differential diagnoses. It is also strongly suggested to combine FNA cytology result with the clinical dan radiological data to come to a better conclusion for correct case management.
In conclusion, the present study shows the result of FNA cytology on salivary gland lesions with 3 false negative cases, one false positive case, four cases of missed neoplastic diagnoses in benign lesions and 6 cases with discrepant type of malignancy. Diagnostic accuracy in differentiating malignant or non-malignant lesions has sensitivity $82.35 \%$ and specificity $95.45 \%$. Although the accuracy of FNA cytology salivary gland lesions is variable and cannot establish a definitive diagnosis, it still can provide clinicians to determine the case management.

\section{REFERENCES}

1. Eveson JW, Auclair P, Gnepp DR, El-Naggar AK. Tumours of the salivary glands. In: Barnes L, Eveson JW, Reichart P, Sidransky D, editors. Pathology and genetics of head and neck tumours. Lyon: IARC Press; 2005. p. 210-76.

2. Badan Registrasi Kanker Perhimpunan Dokter Spesialis Patologi Indonesia. Kanker di Indonesia tahun 2005 data histopatologik. Indonesian.

3. Zhang S, Bao R, Bagby J, Abreo F. Fine needle aspiration of salivary glands 5 year experience from a single academic center. Acta Cytol. 2009;53:375-82.

4. Ersöz C, Uguzi AH, Tuncer U, Soylu L, Kiroglu M. Fine needle aspiration cytology of the salivary glands: a twelve years' experience. Aegean Pathol J. 2004;1:51-6.

5. Ellis GL, Auclair PL. Atlas of tumor pathology: tumors of the salivary glands. 4th series. Fascicle 9. Washington DC: Armed Forced Institute of Pathology; 2008. p. 27-247.

6. Faquin WC, Powers CN. Salivary gland cytopathology. New York: Springer; 2008. p. 85-197.

7. Lurie M, Misselevitch I, Fradis M. Diagnostic value of fine needle aspiration from parotid gland lesions. Isr Med Assoc J. 2002;4:681-3.

8. Jan IS, Chung PF, Weng MH, Huang MS, Lee YT, Cheng TY, et al. Analysis of fine needle aspiration cytology of the salivary gland. J Formos Med Assoc. 2008;107:364-70.

9. Mukunyadzi P. Review of fine-needle aspiration cytology of salivary gland neoplasms, with emphasis on differential diagnosis. Am J Clin Pathol. 2002;118:100-15.

10. Elhosseiny A. Salivary glands. In: Koss LG, editor. Koss' diagnostic cytology. 5th ed. Philadelphia: Lippincott Williams \& Wilkins; 2007. p. 1229-58.

11. Lukas J, Duskova J. Fine needle aspiration biopsy in the diagnostic of the tumors and non-neoplastic lesions of salivary glands. Bratisl Lek Listy. 2006;107:12-5.

12. Colella G, Cannavale R, Flamminio F, Foschini MP. Fineneedle aspiration cytology of salivary gland lesions: a systematic review. J Oral Maxillofac Surg. 2010;68:2146-53. 